\title{
Ecotourism Contributions to Conservation of African Big Cats
}

\begin{abstract}
Ecotourism has been advocated and adopted widely to provide financial, political and local community support for conservation. We analyse its application for conservation of African big cats, through systematic analysis of 66 published studies over three decades, and on-site audit of 48 current conservation tourism enterprises. Conservation measures include: expanding and restoring habitat and reducing net habitat loss; anti-poaching patrols and programs; measures to combat illegal wildlife trade; improved livestock husbandry such as better fences and guard dogs; welldesigned livestock compensation and predator conservation incentive programs; and live-capture, veterinary services, captive breeding, and translocation and reintroduction programmes. Some tourism enterprises do contribute to conservation of African big cats, but others have negligible or negative net outcomes. Conservation outcomes depend critically on the detailed design of conservation programmes, community involvement, and tourism marketing.
\end{abstract}

Keywords: lion; leopard; cheetah; community; tourism; NGO; habitat; poaching; translocation

\section{Introduction \& Methods}

Tourism has become an increasingly significant tool in conservation of threatened species worldwide, providing political and economic support across all land tenures (Balmford et al. 2015; Buckley 2009, 2014; Gubbi \& Poornesha 2013; Lindsey et al., 2005; Meena et al. 2014). This applies particularly in developing nations, where conservation areas are under continuing threats from encroachment and poaching, and have limited funds for operational management (Balmford et al. 2015; Buckley 2010, 2014; Buckley \& Pegas 2014, 2015; Dickman et al. 2011; Lindsey et al. 2013a, Nelson 2009; Packer et al. 2013). Tourism may also produce negative ecological impacts on the same threatened species, through a variety of direct and indirect mechanisms (Buckley 2011, Leung et al. 2015, Monz et al. 2013). Tourism yields negative net overall environmental effects at global scale (Buckley 2011, Gossling \& Peeters 2015) but positive contributions to conservation for some sites at local scale (Buckley 2010; Buckley \& Pabla, 2012; Funston et al. 2013; Sims-Castley et al. 2005; Snyman 2012) and for some species at global scale (Buckley et al., 2012). Some of these species themselves act as tourism attractions, whereas others benefit indirectly. 
Here we analyse the mechanisms by which tourism contributes to conservation of lion (Panthera leo), leopard (Panthera pardus) and cheetah (Acinonyx jubatus), a small group of species which act as iconic tourism attractions at continental scale (Bond et al. 2004; Castley et al. 2013; Cousins et al. 2008; Dickman et al. 2011; Lindsey et al. 2007; 2012; Macdonald \& Loveridge 2010; Nelson 2009; Okello 2005; Okello et al. 2008; Ripple et al. 2014). Public and private wildlife reserves routinely reintroduce big cats, to attract tourists as well as to conserve cats (Buk \& Marnewick 2010; Castley et al. 2001; Hayward et al. 2007; Hunter et al. 2007; Sims-Castley et al. 2005; Trinkel et al. 2008). African big cats have also been the focus of a number of large-scale international conservation efforts (Balme et al. 2009; 2010; Dickman et al. 2011; Hazzah et al. 2009, 2014). Because of the high profile of the African big cats in both tourism and conservation, these species provide a good opportunity to test the use of tourism as a conservation tool.

The conservation status of African big cats is severe (IUCN, 2015). Populations of lion have fallen from a pre-European estimate of 400,000 (Joubert \& Joubert 2011), to around 20-30,000 (Bauer \& Van Der Merwe 2004; Riggio et al. 2013). There are only ten remaining genetically diverse subpopulations with over 1000 lions each (Riggio et al. 2013), largely in protected areas (Dolrenry et al. 2014; Dubach et al. 2013; Henschel et al. 2014; Hunter et al. 2007). The remaining range of leopard has shrunk by up to $40 \%$, and nearly $90 \%$ of remaining habitat is on private rangeland (Balme et al. 2009, 2010; Hayward et al. 2006; Swanepoel 2008). Cheetah have lost over 75\% of their historical range, and the total remaining population is below 10,000, mostly outside protected areas, with the largest subpopulation of 2500 in Namibia (Buk \& Marnewick 2010; Marker \& Dickman 2004; Marker et al. 2003; Marker et al. 2008). The population effects of range reduction are exacerbated by low genetic diversity in remaining populations (Buk \& Marnewick 2010; O’Brien \& Evermann 1988).

All the African big cat species face similar threats (Winterbach et al. 2013). Habitat loss is widespread, principally through conversion to rangeland, farmland or residential areas (Inskip \& Zimmermann 2009; Nowell \& Jackson 1996; Ripple et al. 2014). Livestock owners, whether private or communal, industrial or subsistence, regularly kill predators (Balme et al. 2009; 2010; Frank et al. 2006; Kissui 2008; Lichtenfeld et al. 2014; Maclennan et al. 2009; Packer et al. 2013). Livestock grazing also reduces the abundance and availability of those native species that constitute the big cats' usual prey (Hayward \& Kerley 2005; Hayward et al. 2006). Organised poaching for international criminal trade in animal body parts is widespread (Macdonald \& Loveridge 2010). Poaching may also occur at smaller scale to supply animal parts for traditional medical rituals (Simelane \& Kerley 1998). Some species, notably lions in the Maasai lands of southern Kenya and Page | 2 
northern Tanzania, were hunted traditionally for cultural reasons. Individual animals are killed by commercial hunters, sometimes beyond local population capacities (Buckley et al. 2012; Buckley \& Mossaz 2015; Lindsey et al. 2006, 2012).

Similar conservation threats, efforts and measures also apply for felines in other continents. These include: tiger (Panthera tigris), Gir lion, leopard and snow leopard (P. uncia) in Asia; jaguar and puma (P. onca, P. concolor) in the Americas, and Iberian lynx (Lynx pardinus) in Europe (Breitenmoser 1998; Buckley \& Pabla 2012; Gubbi \& Poornesha 2013; Inskip \& Zimmermann 2009; Karanth \& Chellam 2009; Li et al. 2013; Meena et al. 2014; Nowell \& Jackson 1996; Sharma et al. 2014; Weber \& Rabinowitz 1996; Wolfe et al. 2015; Zimmermann et al. 2005).

For the African big cat species, the interactions between conservation threats, conservation efforts, and conservation tourism (Buckley, 2010a,b) are thus increasingly critical to their continuing survival. Here we examine how tourism contributes to conservation in the face of threats. We identify and classify the various mechanisms involved, by reviewing published studies and conducting on-site field audits. The former indicate the range of conservation mechanisms involved and their historical development. The latter demonstrate patterns in current adoption and practice. We combine these two data sources to generate a menu of mechanisms for the effective use of tourism as a tool in conservation of these and other threatened species. We use the term ecotourism to refer to nature-based tourism which includes education, minimal-impact management, and some contribution to conservation (Buckley, 1994), and conservation tourism to mean tourism which aims to generate a net gain for conservation, over and above negative impacts (Buckley 2010 a,b).

To analyse published studies, we conducted a systematic search of past publications on tourism, conservation and African big cats, using Google Scholar ${ }^{\circledR}$ and Web of Science ${ }^{\circledR}$ for articles in English from 1981-2014, and forward and backward citation tracking. We coded these publications into research themes, adding and revising themes until saturation was reached, and analysed patterns amongst themes and publications using principal components analysis (Primer® Ver. 6.1.11). To analyse practices in the field, we conducted brief on-site audits following the approach reported by Buckley (2003, 2010). We also interviewed staff and stakeholders in person, by phone or by email, and searched for more detailed and updated information using project websites, blogs, marketing materials, and mass and social media.

\section{Results}


We identified 66 publications that focussed on conservation management of African big cats and included the role of tourism. Coding yielded 12 themes, reflecting the scale of analysis, ecological outcomes, social aspects, tourist attitudes, and policy and management measures. The 66 publications, and the 12 coded research themes, are listed in Supplementary Table 1. Eighteen of these 66 studies, summarised in Table 1, present detailed information on conservation measures and mechanisms. Of the 66 published studies, 75\% considered lion, 48\% leopard and 42\% cheetah. One third were from South Africa; 85\% were published since 2006; 45\% used timeframes $\leq 2$ years; 55\% used social-science methods; 29\% reported experimental ecological studies. Those addressing social aspects considered a wider range of issues than those investigating biological aspects (chisquare $=56.03, \mathrm{P}<0.01)$. Human-felid conflicts (44\%) and livestock compensation schemes $(12 \%)$ were heavily studied. Only one publication mentioned the negative ecological impacts of tourism.

Ecotourism (38\%) and trophy hunting (32\%) were equally favoured as tools for conservation. Of those recommending ecotourism, 24\% (6/25) noted the importance of big cats in attracting international visitors, and 36\% (9/25) argued that ecotourism raised awareness of big cat conservation amongst international tourists. Principal component analysis of the 12 coded research themes yielded similar results. The first component distinguished studies addressing direct ecological gains (loading -0.61) from those assessing indirect measures, through management of human-wildlife conflict (+0.63). The second axis distinguished studies assessing socioeconomic gains through ecotourism (-0.65), from those considering more indirect mechanisms $(+0.41)$. Ecotourism is also associated with changes in tourist attitudes (-0.42).

We conducted onsite field audits and interviews at 48 sites in six countries, operated by 13 tourism operators and NGO’s: African Parks, \&Beyond (18 sites), Great Plains Conservation (5 sites), Kuzuko Private Reserve, Lewa Wildlife Conservancy, Madkiwe Private Reserve, Moholoholo Wildlife Rehabilitation Program, Northern Tuli Game Reserve, Okonjima Game Reserve, Robin Pope Safaris, Sabi Sabi Private Reserve, Shamwari Game Reserve, and Wilderness Safaris (12 sites). We also examined the work of six further NGO's which do not manage specific areas directly: Big Cats Initiative, Big Life Foundation, Cheetah Conservation Fund, Panthera, Tourism Supporting Conservation (TOSCO), and the Wilderness Trust. Websites are listed in Supplementary Table 2.

Field audits identified an extensive set of mechanisms by which tourism enterprises run by private firms, local communities and NGO's contribute in practice to the conservation of lion, leopard and cheetah. These mechanisms are summarised in Table 2, which also cross-references previous Page | 4 
published studies. The main measures are: securing, expanding and improving habitat areas; expanding anti-poaching patrols and programs; combating illegal wildlife trade; improving livestock husbandry using better fences and guard dogs; well-designed livestock compensation schemes and predator conservation incentives; and live-capture, veterinary services, captive breeding, and translocation and reintroduction programmes.

The mechanisms referred to most frequently in previous publications were first, economic incentives for private landowners to tolerate predators despite livestock losses; and second, logistic support for reintroduction programs, including monitoring. Less frequently mentioned mechanisms included: establishment of private or communal reserves; conservation management of public land on concessions; creation of corridors linking sub-populations, e.g. by removing fences; translocations to improve genetic diversity; and funding for anti-poaching patrols. The principal approaches adopted at the sites audited in person, however, were first, protection of habitat through establishment of concessions, conservation leases and private reserves; second, active anti-poaching measures such as patrols, snare buyback schemes, and monitoring and surveillance; and third, various translocation, semi-captive breeding, and field veterinary services.

For livestock compensation programs, key components include: payment at accurate market value for individual animals, assessed locally by an unbiased process; rapid payment, once a right to compensation is determined; and reductions in payments from contributory negligence through poor livestock management, such as failing to bring individual animals into a guarded boma (stockade) at night. For anti-poaching patrols, technological support such as the use of surveillance drones and night vision goggles is increasingly widespread. Good relations with local communities whose members can rapidly report any incursions, however, also remains critical. Equally significant is the legal basis under which anti-poaching personnel operate: for example, whether they are empowered to pursue suspected poachers outside their own boundaries, whether they are have the authority to make arrests, and when they are permitted to use firearms. For translocation programs, live-capture, veterinary, transport and soft-release techniques have evolved greatly over recent years, with a corps of practical knowledge and experience adapted for different species, leading to successful translocations across international borders with no losses.

The measures adopted depend on the scale and structure of the tourism operations involved. Larger businesses, sometimes in cooperation or partnership, devote more resources to cross-border approaches. Smaller operators necessarily focus their efforts at local scale. Conservancies and concessions managed by tourism companies, trusts and NGO's have converted tens of thousands of Page | 5 
square kilometres to conservation, and manage those areas actively to protect threatened species, including big cats. Acting together, they have expanded the scope of public protected areas, removed fences between adjacent reserves, and created corridors to link subpopulations.

\section{Discussion}

Results presented above indicate that at regional scale, there are indeed many mechanisms by which tourism makes substantial and significant contributions to conservation of African big cats. These contributions occur across all land tenures (Table 3). At some sites, these contributions are net positive at local scale. They are closely cross-linked to contributions from government agencies, donors and NGOs. These linkages differ among sites, and have been little studied (Lindsey et al. 2009, 2013; van Wijk et al. 2015).

For any of these measures to make a significant contribution to conservation requires adequate scale and population numbers, and appropriate management to minimise negative impacts (Balme et al. 2009; Geldmann et al. 2013; Hayward et al. 2012; Lindsey et al. 2006, 2009, 2012, 2013). At metapopulation level, conservation of big cats requires landscape-level approaches incorporating the establishment of protected areas on private and communal land, the management of public land on concessions, the removal of fences in conservancies, and the creation of corridors linking subpopulations (Dolrenry et al. 2014; Lindsey et al. 2013; Packer et al. 2013).

As a result, whilst some tourism operations involving big cats do contribute to conservation, others do not (Balme et al. 2010; Cousins et al. 2008; Hayward et al. 2007; Hunter et al. 2007). Examples of those which do not include: reintroductions to small private reserves, too fragmented to improve genetic diversity; tourism products which involve close interactions between big cats and tourists; and farms which breed big cats for semi-captive hunting (Druce et al. 2004; Hayward et al. 2007; Hazzah et al. 2014; Hunter et al. 2012; Lindsey et al. 2012; Marker et al. 2008; Romañach et al. 2010; Slotow \& Hunter 2009).

A critical component for many of the more successful initiatives is the involvement of local communities. This may involve employment opportunities, livestock compensation programs, and changes to cultural perceptions (Carlisle 2007; Funston et al. 2013; Goldman et al. 2013; Gusset et al. 2009; Hazzah et al. 2009, 2014; Hemson et al. 2009; Lindsey et al. 2005; 2013; Nelson 2009; Romañach et al. 2010; Snyman 2012). Early compensation schemes yielded limited success, because of poor design, poor implementation, or because cultural values were more important than Page | 6 
money (Goldman et al. 2010; Kgathi et al. 2012), but more recent programs have learned from these lessons (Lichtenfeld et al. 2014).

\section{Conclusions}

We conclude that commercial conservation tourism can indeed make valuable contributions to conservation of African big cats, especially in conjunction with public protected areas and other conservation approaches. The drivers, mechanisms and outcomes of commercial conservation tourism efforts thus merit further research. Priorities for such research may be considered in three categories: ecological, social and economic. The principal ecological research priority is to quantify the aggregate contribution of all these private-sector approaches, using measures that are meaningful for threatened species conservation. Possible approaches include population viability analysis, population accounting (Buckley et al. 2012), or surrogate indicators such as area of habitat, numbers of individuals translocated, and anti-poaching investments (Dalerum et al. 2008). As metapopulation management becomes increasingly widespread, ecological research on range, diet, movement, and genetics of individual subpopulations, will become increasingly critical.

From a social perspective, the cultural concerns of local communities regarding livelihoods, tourism and wildlife, all affect the success of conservation tourism (Carlisle 2007; Dickman et al. 2011; Hemson et al. 2009; Goldman et al. 2013; Okello 2005). Research on these factors, including those that are partially hidden, remains a strong priority. From an economic perspective, all conservation tourism efforts and enterprises depend on commercial viability. This depends in turn on both legal and market factors. Legal factors include the rights associated with different types of land tenure and associated wildlife (Cousins et al. 2008; Lindsey et al. 2009a; Lindsey et al. 2013; Okello 2005; Sims-Castley et al. 2005). Market factors include the willingness of tourists to pay for premium products that contribute to conservation, and the factors that lead travel agents to book clients with conservation tourism operators specifically.

Conservation tourism can be effective, for African big cats as for other species. It is complex, however, because it requires successful integration of ecological, social, legal and market factors, all of which differ among sites and vary between years and seasons. Tourism operators, parks and wildlife agencies, local communities and NGOs continually adopt and trial new approaches, and researchers can contribute by reporting, analysing and communicating information on approaches and outcomes. Lessons learned from Africa may well prove applicable in other continents. 


\section{Acknowledgements}

Field support, information and assistance was kindly provided by: African Parks, \&Beyond, Great Plains Conservation, Kuzuko Private Reserve, Lewa Wildlife Conservancy, Madkiwe Private Reserve, Moholoholo Wildlife Rehabilitation Program, Northern Tuli Game Reserve, Okonjima Game Reserve, Robin Pope Safaris, Sabi Sabi Private Reserve, Shamwari Game Reserve, and Wilderness Safaris ; and by the Big Cats Initiative, Big Life Foundation, Cheetah Conservation Fund, Panthera, Tourism Supporting Conservation (TOSCO), and the Wilderness Trust.

\section{References}

Balme, G.A., Slotow, R., \& Hunter, L.T.B. (2009). Impact of conservation interventions on the dynamics and persistence of a persecuted leopard (Panthera pardus) population. Biological Conservation, 142, 2681-2690.

Balme, G.A., Slotow, R., \& Hunter, L.T.B. (2010). Edge effects and the impact of non-protected areas in carnivore conservation: leopards in the Phinda-Mkhuze Complex, South Africa. Animal Conservation, 13, 315-323.

Balmford, A., Green, J. M., Anderson, M., Beresford, J., Huang, C., Naidoo, R., et al. (2015). Walk on the wild side: estimating the global magnitude of visits to protected areas. PLoS Biology 13(2), e1002074.

Bauer, H. \& Van Der Merwe, S. (2004). Inventory of free-ranging lions Panthera leo in Africa. Oryx, 38, 26-31.

Bond, I., Child, B., de la Harpe, D., Jones, B., Barnes, J., \& Anderson, H. (2004). Private land contribution to conservation in South Africa. In B. Child (Ed.), Parks in transition (pp. 29-62). Cardiff: Earthscan.

Buk, K. \& Marnewick, K. (2010). Cheetah conservation in South Africa. Africa Insight, 39, 212224. 
Buckley, R. (1994). A framework for ecotourism. Annals of Tourism Research, 21, 661-665.

Buckley, R. (2003). Case studies in ecotourism. Wallingford: CAB International.

Buckley, R. (2009). Parks and tourism. PLoS Biology, 7(6), e1000143.

Buckley, R. (2010a). Conservation tourism. Wallingford: CAB International.

Buckley, R.C. (2010b). Safaris can help conservation. Nature, 467, 1047.

Buckley, R. (2011). Tourism and environment. Annual Review of Environment and Resources, 36, 397-416.

Buckley, R. (2014). Protecting lemurs: ecotourism. Science, 344, 358

Buckley, R.C., Castley, J.G., Pegas, F. de V., Mossaz, A.C., \& Steven, R. (2012). A population accounting approach to assess tourism contributions to conservation of IUCN-redlisted mammal species. PLoS ONE, 7, e44134.

Buckley, R., \& Mossaz, A. (2015). Hunting tourism and animal conservation. Animal Conservation, $18,133-135$.

Buckley, R., \& Pabla, H.S. (2012). Conservation: tourism ban won’t help Indian tigers. Nature, 489, 33-33.

Buckley, R. \& Pegas, F.de V. (2014). Conserving Brazil’s Atlantic forests. Science, 346, 1193.

Buckley, R. \& Pegas, F.de V. (2015). Four hurdles to conservation in private land: the case of the golden lion tamarin in Brazil's Atlantic Forest. Frontiers in Ecology and Evolution, doi: 10.3389/fevo.2015.00088.

Breitenmoser, U. (1998). Large predators in the Alps: The fall and rise of man's competitors. Biological Conservation, 83, 279-289. 
Carlisle, L. (2007). Conservation and community development: the Conservation Corporation Africa model. In R. Bushell \& P.J.F. Eagles (Eds.), Tourism and protected areas: benefits beyond boundaries (pp. 244-265). Wallingford: CAB International.

Castley, J.G., Boshoff, A.F., \& Kerley, G.I.H. (2001). Compromising South Africa's natural biodiversity - inappropriate herbivore introductions. South African Journal of Science, 97, 344-348.

Castley, J.G., Bennett, A., \& Pickering, C.M. (2013). Wildlife visual imagery: do pictures used to promote destinations online match on-site species visibility at two geographic destinations? Geographical Research, 51, 59-70.

Cousins, J.A., Sadler, J.P., \& Evans, J. (2008). Exploring the role of private wildlife ranching as a conservation tool in South Africa: stakeholder perspectives. Ecology and Society, 13, 43.

Dalerum, F., Somers, M., Kunkel, K., \& Cameron, E. (2008). The potential for large carnivores to act as biodiversity surrogates in southern Africa. Biodiversity Conservation, 17, 2939-2949.

Dickman, A.J., Macdonald, E.A., \& Macdonald, D.W. (2011). A review of financial instruments to pay for predator conservation and encourage human-carnivore coexistence. Proceedings of the National Academy of Sciences, 108, 13937-13944.

Dolrenry, S., Stenglein, J., Hazzah, L., Lutz, R.S., \& Frank, L. (2014). A metapopulation approach to African lion (Panthera leo) conservation. PLoS ONE, 9, e88081.

Druce, D., Genis, H., Braak, J., Greatwood, S., Delsink, A., Kettles, R. et al. (2004). Population demography and spatial ecology of a reintroduced lion population in the Greater Makalali Conservancy, South Africa. Koedoe, 47, 103-118.

Dubach, J.M., Briggs, M.B., White, P.A., Ament, B.A., \& Patterson, B.D. (2013). Genetic perspectives on "Lion Conservation Units” in Eastern and Southern Africa. Conservation Genetics, 14, 741-755.

Funston, P.J., Groom, R., \& Lindsey, P.A. (2013). Insights into the management of large carnivores for profitable wildlife-based land uses in African savannas. PLoS ONE, 8, e59044. 
Frank, L., Hemson, G., Kushnir, H., \& Packer, C. (2006). Lions, conflict and conservation in Eastern and Southern Africa. In: Background paper for the eastern and southern African lion conservation workshop, Johannesburg, South Africa, 11-13 January 2006.

Geldmann, J., Barnes, M., Coad, L., Craigie, I.D., Hockings, M., \& Burgess, N.D. (2013). Effectiveness of terrestrial protected areas in reducing habitat loss and population declines. Biological Conservation, 161, 230-238.

Goldman, M.J., de Pinho, J.R., \& Perry, J. (2013). Beyond ritual and economics: Maasai lion hunting and conservation politics. Oryx, 47, 490-500.

Gössling, S. \& Peeters, P. (2015). Assessing tourism's global environmental impact 1900-2050. Journal of Sustainable Tourism, 23, 639-659.

Gubbi, S. \& Poornesha, H.C. (2013). Conservation: joint Indian initiative creates tiger corridor. Nature, 500, 29-29.

Gusset, M., Swarner, M.J., Mponwane, L., Keletile, K., \& McNutt, J.W. (2009). Human-wildlife conflict in northern Botswana: livestock predation by Endangered African wild dog Lycaon pictus and other carnivores. Oryx, 43, 67-72.

Hayward, M.W.H., \& Kerley, G.I.H. (2005). Prey preferences of the lion (Panthera leo). Journal of Zoology, 267, 309-322.

Hayward, M.W., Henschel, P., O’Brien, J., Hofmeyr, M., Balme, G., \& Kerley, G.I.H. (2006). Prey preferences of the leopard (Panthera pardus). Journal of Zoology, 270, 298-313.

Hayward, M.W., Kerley, G.I.H., Adendorff, J., Moolman, L.C., O'Brien, J., Sholto-Douglas, A., et al. (2007). The reintroduction of large carnivores to the Eastern Cape, South Africa: an assessment. Oryx, 41, 205-214.

Hayward, M.W., Somers, M.J., Kerley, G.I.H., Perrin, M.R., Bester, M.N., Dalerum, F., et al. (2012). Animal ethics and ecotourism. South African Journal of Wildlife Research, 42, 3-5. 
Hazzah, L., Mulder, M.B., \& Frank, L. (2009). Lions and warriors: social factors underlying declining African lion populations and the effect of incentive-based management in Kenya. Biological Conservation, 142, 2428-2437.

Hazzah, L., Dolrenry, S., Naughton, L., Edwards, C.T.T., Mwebi, O., Kearney, F., \& Frank, L. (2014). Efficacy of two lion conservation programs in Maasailand, Kenya. Conservation Biology, 28, 851-860.

Hemson, G., Maclennan, S., Mills, G., Johnson, P., \& Macdonald, D. (2009). Community, lions, livestock and money: A spatial and social analysis of attitudes to wildlife and the conservation value of tourism in a human-carnivore conflict in Botswana. Biological Conservation, 142, 27182725.

Henschel, P., Coad, L., Burton, C., Chataigner, B., Dunn, A., MacDonald, D., et al. (2014). The lion in West Africa is Critically Endangered. PLoS ONE, 9, e83500.

Hunter, L.T.B., Pretorius, K., Carlisle, L.C., Rickelton, M., Walker, C., Slotow, R., \& Skinner, J.D. (2007). Restoring lions Panthera leo to northern KwaZulu-Natal, South Africa: short-term biological and technical success but equivocal long-term conservation. Oryx, 41, 196-204.

Hunter, L.T.B., White, P., Henschel, P., Frank, L., Burton, C., Loveridge, A., et al. (2012). Walking with lions: why there is no role for captive-origin lions Panthera leo in species restoration. Oryx, 47, $19-24$.

Inskip, C. \& Zimmermann, A. (2009). Human-felid conflict: a review of patterns and priorities worldwide. Oryx, 43, 18-34.

IUCN (2015). The IUCN Red List of Threatened Species. www.iucnredlist.org Accessed 22 September 2015.

Joubert, D. \& Joubert, B. (2011). The Last Lions. Washington, D.C.: National Geographic Films.

Karanth, K.U. \& Chellam, R. (2009). Carnivore conservation at the crossroads. Oryx, 43, 1-2. 
Kgathi, D. L., Mmopelwa, G., Mashabe, B., \& Mosepele, K. (2012). Livestock predation, household adaptation and compensation policy: a case study of Shorobe Village in northern Botswana. Agrekon, 51(2), 22-37.

Kissui, B.M. (2008). Livestock predation by lions, leopards, spotted hyenas, and their vulnerability to retaliatory killing in the Maasai steppe, Tanzania. Animal Conservation, 11, 422-432.

Leung,Y.F., Spenceley,A., Hvenegaard, G. and Buckley, R. (eds) (2015). Tourism and visitor management in protected areas. Gland: IUCN

Li, J., Yin, H., Wang, D., Jiagong, Z., \& Lu, Z. (2013). Human-snow leopard conflicts in the Sanjiangyuan Region of the Tibetan Plateau. Biological Conservation, 166, 118-123.

Lichtenfeld, L.L., Trout, C., \& Kisimir, E.L. (2014). Evidence-based conservation: predator-proof bomas protect livestock and lions. Biodiversity Conservation, 24, 483-491.

Lindsey, P.A., Alexander, R.R., du Toit, J.T., \& Mills, M.G.L. (2005). The potential contribution of ecotourism to African wild dog Lycaon pictus conservation in South Africa. Biological Conservation, 123, 339-348.

Lindsey, P.A., Alexander, R., Frank, L.G., Mathieson, A., \& Romañach, S.S. (2006). Potential of trophy hunting to create incentives for wildlife conservation in Africa where alternative wildlifebased land uses may not be viable. Animal Conservation, 9, 283-291.

Lindsey, P.A., Romañach ,S.S., \& Davies-Mostert, H.T. (2009). The importance of conservancies for enhancing the value of game ranch land for large mammal conservation in southern Africa. Journal of Zoology, 277, 99-105.

Lindsey, P.A., Balme, G.A., Booth, V.R., \& Midlane, N. (2012). The significance of African lions for the financial viability of trophy hunting and the maintenance of wild land. PLOS ONE, 7, e29332.

Lindsey, P.A., Balme, G.A., Funston, P., Henschel, P., Hunter, L., Madzikanda, H., et al. (2013a). The trophy hunting of African lions: scale, current management practices and factors undermining sustainability. PLoS ONE, 8, e73808.

Page | 13 
Lindsey, P.A., Havemann, C.P., Lines, R.M., Price, A.E., Retief, T.A., Rhebergen, T., et al. (2013b). Benefits of wildlife-based land uses on private lands in Namibia and limitations affecting their development. Oryx, 47, 41-53.

Macdonald, D.W. \& Loveridge, A.J. (2010). The biology and conservation of wild felids. Oxford: Oxford University Press.

Maclennan, S.D., Groom, R.J., Macdonald, D.W., \& Frank, L.G. (2009). Evaluation of a compensation scheme to bring about pastoralist tolerance of lions. Biological Conservation, 142, 2419-2427.

Marker, L.L., Mills, M.G.L. \& Macdonald, D.W., (2003). Factors influencing perceptions of conflict and tolerance toward cheetahs on Namibian farmlands. Conservation Biology, 17, 12901298.

Marker, L. \& Dickman, A. (2004). Human aspects of cheetah conservation: lessons learned from the Namibian farmlands. Human Dimension of Wildlife, 9, 297-305.

Marker, L.L., Dickman, A.J., Mills, M.G.L., Jeo, R.M., \& Macdonald, D.W. (2008). Spatial ecology of cheetahs on north-central Namibian farmlands. Journal of Zoology, 274, 226-238.

Meena, V., Macdonald, D.W., \& Montgomery, R.A. (2014). Managing success: Asiatic lion conservation, interface problems and peoples’ perceptions in the Gir Protected Area. Biological Conservation, 174, 120-126.

Monz, C.A., Pickering, C.M., \& Hadwen, W.L. (2013). Recent advances in recreation ecology and the implications of different relationships between recreation use and ecological impacts. Frontiers in Ecology and the Environment, 11(8), 441-446.

Nelson, F. (2009). Developing payments for ecosystem services approaches to carnivore conservation. Human Dimension of Wildlife, 14, 381-392.

Nowell, K. \& Jackson, P. (1996). Wild cats: a status survey and conservation action plan. Gland: IUCN/SSC Cat Specialist Group.

Page | 14 
O'Brien, S.J. \& Evermann, J.F. (1988). Interactive influence of infectious disease and genetic diversity in natural populations. Trends in Ecology and Evolution, 3, 254-259.

Okello, M.M. (2005). A survey of tourist expectations and economic potential for a proposed wildlife sanctuary in a Maasai group ranch near Amboseli, Kenya. Journal of Sustainable Tourism, 13, 566-589.

Okello, M.M., Manka, S.G., \& D'Amour, D.E. (2008). The relative importance of large mammal species for tourism in Amboseli National Park, Kenya. Tourism Management, 29, 751-760.

Packer, C., Loveridge, A., Canney, S., Caro, T., Garnett, S.T., Pfeifer, M. et al. (2013). Conserving large carnivores: dollars and fence. Ecology Letters, 16, 635-641.

Riggio, J., Jacobson, A., Dollar, L., Bauer, H., Becker, M., Dickman, A., et al. (2013).The size of savannah Africa: a lion’s (Panthera leo) view. Biodiversity Conservation, 22, 17-35.

Ripple, W.J. Estes, J.A., Beschta, R.L., Wilmers, C.C., Ritchie, E.G., Hebblewhite, M., et al. (2014). Status and ecological effects of the world's largest carnivores. Science, 343, 1241484 1241511.

Romañach, S.S., Lindsey, P.A., \& Woodroffe, R. (2010). Attitudes toward predators and options for their conservation in the Ewaso Ecosystem. Smithsonian Contributions to Zoology, 632, 85-93.

Sharma, K., Wright, B., Joseph, T, \& Desai, N. (2014). Tiger poaching and trafficking in India: Estimating rates of occurrence and detection over four decades. Biological Conservation, 179, 3339.

Simelane, T.S. \& Kerley, G.I.H. (1998). Conservation implications of the use of vertebrates by Xhosa traditional healers in South Africa. South African Journal of Wildlife Research, 28, 121-126.

Sims-Castley, R., Kerley, G.I.H., Geach, B., \& Langholz, J. (2005). Socio-economic significance of ecotourism-based private game reserves in South Africa's Eastern Cape Province. Parks, 15, 6-18. 
Slotow, R., \& Hunter, L.T.B. (2009). Reintroduction decisions taken at the incorrect social scale devalue their conservation contribution: the African lion in South Africa. In M. W. Hayward and M. J. Somers (Eds.), Reintroduction of top-order predators (pp. 43-71). Oxford: Wiley-Blackwell.

Snyman, S.L. (2012). The role of tourism employment in poverty reduction and community perceptions of conservation and tourism in southern Africa. Journal of Sustainable Tourism, 20, 395-416.

Swanepoel, L.H. (2008). Ecology and conservation of leopards, Panthera pardus, on selected game ranches in the Waterberg region, Limpopo, South Africa. Pretoria: University of Pretoria (167 pp).

Trinkel, M., Ferguson, N., Reid, A., Reid, C., Somers, M., Turelli, L. et al. (2008). Translocating lions into an inbred lion population in the Hluhluwe-iMfolozi Park, South Africa. Animal Conservation, 11, 138-143.

Van Wijk, J., van der Duim, R., Lamers, M. \& Sumba, D., (2015). The emergence of institutional innovations in tourism: the evolution of the African Wildlife Foundation's tourism conservation enterprises. Journal of Sustainable Tourism, 23, 104-125.

Weber, W. \& Rabinowitz, A. (1996). A global perspective on large carnivore conservation. Conservation Biology, 10, 1046-1054.

Winterbach, H.E.K., Winterbach, C.W., Somers, M.J., \& Hayward, M.W. (2013). Key factors and related principles in the conservation of large African carnivores. Mammal Review, 43, 89-110.

Wolfe, M.L., Koons, D.N., Stoner, D.C., Terletzky, P., Gese, E.M., Choate, D.M., \& Aubry, L.M. (2015). Is anthropogenic cougar mortality compensated by changes in natural mortality in Utah? Insight from long-term studies. Biological Conservation, 182, 187-196.

Zimmermann, A., Walpole M.J., \& Leader-Williams, N. (2005). Cattle ranchers' attitudes to conflicts with jaguar Panthera onca in the Pantanal of Brazil. Oryx, 39, 406-412. 